\title{
QUALITY OF INDIAN MACKEREL AS AFFECTED BY POMEGRANATE PEEL AND TEA LEAF EXTRACTS DURING ICE STORAGE
}

\author{
P.A. Shinde, V.K. Reddy. $S^{* 1}$ and S.B. Patange \\ Department of Fish Processing Technology and Microbiology, Fisheries College, Shirgaon, Ratnagiri, \\ Maharashtra, India -415 629
}

\begin{abstract}
The effect of dip treatments of Indian mackerel (Rastriliger kanagurta) in $0.5 \%$ \& $1 \%$ pomegranate peel extracts (Punica granatum) (PPE) and 3 $\%$ \& $5 \%$ green tea (Camelia sinensis) (GTE) extracts; on the ice storage characteristics was evaluated. Total phenolic content of PPE and GTE were found to be $212 \pm 20.55$ and $159.3 \pm 7.72 \mathrm{mg} \mathrm{g}^{-1}$ tannic equivalent. Fish treated with PPE and GTE were evaluated for bio-chemical, microbiological and sensory attributes during the period of storage in ice. Indicator organisms like Escherichia coli, and Staphylococcus aureus were not detected in any sample, whereas biochemical attributes increased significantly $(p<0.05)$ during the storage period. The fishes were acceptable up to 17th and 16th days in ice in case of PPE \& GTE treatments, respectively. On the other hand the untreated fish was acceptable only up to 8 days. From this study it is concluded that; the natural extracts of PPE \& GTE can be used to preserve the fatty fish and extend the shelf life during ice storage for a considerable period.
\end{abstract}

Keywords: Plant extracts, Indian mackerel, Biochemical, Microbiological and Sensory analysis, Ice storage

\section{INTRODUCTION}

Fish is one of the most perishable and difficult to handle of all foods. It is mainly due to the catching method that has no control on its initial quality, which results in variation of intrinsic quality of raw material. Icing is the easiest, cheapest, reasonably efficient and common method of preserving fresh fish. Iced fish has a limited shelf life. Fish can be stored in ice and maintained in good conditions for 315 days depending on species and various intrinsic factors. Fatty fishes like sardines have a limited shelf life of only 2-5 days in ice (Balachandran et al., 2001), whereas lean fishes will have a little more. This period is inadequate for long distance

"Corresponding author email: vijayreddy.surasani@rediffmail.com

${ }^{1}$ Department of Fish Processing Technology, College of Fisheries, Hoige Bazar, Mangalore, Karnataka, India

Received: 27.11 .2014 
transport of fish, as most of the fishes are not caught near the landing spots. In addition the landing spots are often far from ultimate place of consumption. Therefore, further extension of shelf life could be of great practical significance; particularly for the developing countries, where fast moving refrigeration system is lacking. There are several other preservatives, mainly chemicals used in combination with icing to increase the shelf life of ice stored fish. The demand for natural extracts, which act as preservative is gaining importance due to the negative effects and health problems associated with chemical preservatives. Plant extracts like green tea (Camelia sinensis), grape seed (Vitis vinifera) and pomegranate peel (Punica granatum) extracts have been studied for their preservative effect when used in foods and the results were positive. In this study, plant extracts i.e. pomegranate peel and green tea extracts were tested for their preservative effects on the ice stored Indian mackerel (Rastrelliger kanagurta).

\section{MATERIALS AND METHODS}

\section{Preparation of extracts and storage}

Pomegranate (Punica granatum) were purchased from the local market and peeled manually. Pomegranate peels (PP) were dried at $50{ }^{\circ} \mathrm{C}$ until a constant weight and ground to powder. Powder was dissolved in ethanol $(1: 20 \mathrm{w} / \mathrm{v})$ and then extracted in water bath with shaker at $40{ }^{\circ} \mathrm{C}$ for $4 \mathrm{~h}$. The extract was filtered and concentrated in a water bath to get crude extract.

Antique green tea (GT) dried leaves (Camelia sinensis) were purchased from the local market in Ratnagiri. Leaves were ground into fine powder. The powder was dissolved in ethanol $(1: 20 \mathrm{w} / \mathrm{v})$ and then the active ingredients were extracted using a water bath with shaker at $40{ }^{\circ} \mathrm{C}$ for $4 \mathrm{~h}$. The extract was filtered and concentrated to get crude extract.

The green tea and pomegranate peel extracts were stored in a refrigerator in air tight bottles.

\section{Treatment with extracts}

Extract solution was prepared by dissolving $1.0 \mathrm{~g}$ plant extract in $100 \mathrm{ml}$ distilled water. Fishes were separately dipped into two extract solutions i.e. pomegranate peel (PP) and green tea (GT) extracts, stored at $0^{\circ} \mathrm{C}$. Another group of fishes were dipped into water and used as control.

\section{Analyses}

Quality control analyses of fish were performed regularly during the entire storage period.

\section{Total Phenolics in Plant Extracts}

Total phenolic contents of the extracts were determined spectrophotometrically according to the Folin-Ciocalteu colorimetric method (Spanos and Wrolstad, 1990). 
Each extract of $0.1 \mathrm{ml}$ was introduced to $5 \mathrm{ml}$ Folin-Ciocalteu's reagent (10\%), $4 \mathrm{ml}$ sodium carbonate $(10 \%)$ and $0.9 \mathrm{ml}$ distilled water. The mixture was allowed to stand for 2 hours before absorbance measurement against blank at $765 \mathrm{~nm}$ (Genensys $10 \mathrm{UV}$ ). Results were expressed as mg tannic acid equivalent (GAE) in mg $100 \mathrm{~g}^{-1}$.

\section{Sensory analysis}

Sensory characteristics i.e. appearance, color, odor, taste, texture and overall acceptability were evaluated by a trained panel of 5 members using 9-point hedonic scale according to Peryam and Pilgrim (1957). The limit of acceptability was 4 for all the samples (Table 1). High score indicated good quality and vice versa.

\section{Statistical analysis}

Recorded results were analyzed using appropriate statistical methods (Snedecor and Cochran, 1967). The significant results were stated as $P<0.05$. (Simeonidou et al., 1997).

\section{RESULTS AND DISCUSSION}

\section{Total Phenolics of Plant Extracts}

In the present study, the phenolic content of PP and GT extracts at different concentrations in terms of tannic acid equivalent was estimated using the standard curve equation: $\mathrm{y}=0.174+19.03 \mathrm{x}, \mathrm{r}^{2}=0.967$ obtained from standard curve of known tannic acid concentrations. The phenolic content in pomegranate peel extract (PPE) and green tea extract (GTE) were observed to be $212 \pm 20.55$ and $159.3 \pm 7.72 \mathrm{mg} \mathrm{g}^{-1}$ tannic acid equivalent respectively.

Yerlikaya et al. (2010) reported the total phenolic content of pomegranate peel extract and green tea extract to be $249 \pm 17.2 \& 126 \pm 4.5 \mathrm{mg} \mathrm{g}^{-1}$ tannic acid equivalent, respectively. The values observed in the present study, if compared to that of Yerlikaya et al. (2010), showed that phenolic content was slightly lower in PPE and higher in GTE.

Sarah et al. (2010) reported the total phenolic content in red onion (Allium сера) juice OJ and green tea (Camellia sinenses) TE extracts at different concentrations in terms of TAE (with the standard curve equation: $\mathrm{y}=0.0091+$ $\left.0.0075 \mathrm{x}, \mathrm{r}^{2}=0.9945\right)$. The lowest (3.13 $\left.\mathrm{mg} \mathrm{TAE} \mathrm{g}^{-1}\right)$ and highest $\left(538.2 \mathrm{mg} \mathrm{TAE} \mathrm{g}^{-1}\right)$ contents were found in aqueous solutions of $1 \%$ OJ and $5 \%$ TE respectively. Green tea extract had more phenolic compounds when compared to onion juice at the same concentration. Unalan et al. (2011) reported that the pomegranate peel (Punica granutum) extract had high phenolic content of $481 \mathrm{mg}$ gallic acid equivalent (GAE $\left.\mathrm{g}^{-1}\right)$ dry extract; whereas aqueous rosemary extract (1:1) had $30.2 \mathrm{mg}^{\mathrm{GAE}} \mathrm{g}^{-1}$ dry extract. Ibrahium (2010) also reported relatively higher total polyphenols content in pomegranate peel extract $\left(867 \mathrm{mg} \mathrm{g}^{-1}\right)$. The polyphenolic composition of PPE is characterized by a high proportion of punicalagin $\left(296 \mathrm{mg} \mathrm{g}^{-1}\right)$ in comparison to the remaining compounds. Khammuang and Sarnthima (2011) reported that the total phenolic content in mango (Mangifera indica L.) extract was $399.8 \mathrm{mg} \mathrm{GAE} \mathrm{g}^{-1}$. 


\section{Biochemical analysis}

The TMA-N content was observed to increase progressively in both PPE \& GTE treated samples (Figure 1). However, the increment of TMA-N content was rapid in GTE treated samples than PPE treated samples. The study indicated that the increase in TMA-N value was slow in the PPE treated samples when compared to GTE treated samples. These findings are in agreement with Unalan et al. (2011) for pomegranate (Punica granutum) extract $(1 \% \mathrm{v} / \mathrm{w})$ and rosemary (Rosmarinus officinalis L.) extract $(1 \% \mathrm{v} / \mathrm{w})$ on shelf life extension of frozen and chilled Greenland halibut (Reinhardtius hippoglossoides) fillets. The fillets were kept in modified atmosphere packaging $\left(40 \% \mathrm{CO}_{2} / 60 \% \mathrm{~N}_{2}\right)$ during chilled storage at $2^{\circ} \mathrm{C}$ The TMA-N values were increased significantly $(\mathrm{P}<0.05)$ during the chilled storage and reached nearly limit level at the end of chilled storage. The treatment of mackerel with PPE \& GTE showed significant effect on the levels of TMA-N between treated and untreated fish, whereas no significant difference was found between the treated fish.

During the ice storage of PPE \& GTE treated mackerel the production of nonvolatile amines was not significant even when the fish attained the putrid state. Hence, the use of these amines as overall quality predictors is not advisable.

In the present study TVB-N was $7.12 \pm 0.58 \mathrm{mg} \%$ at the beginning of the storage in PPE treated as well as GTE treated samples. The TVB-N content was observed to increase progressively in both PPE \& GTE treated samples. However, the increment of TVB-N content was rapid in GTE treated samples than PPE treated samples. The lower TVB-N values were recorded in PPE treated sample during storage (Figure 2). The values in treated samples below or close to limit level indicated that the increase in TVB-N value was slow in the PPE treated samples as compared to GTE treated samples. These findings are in agreement with Unalan et al. (2011). The TVB-N values for these treatments significantly increased $(\mathrm{P}<0.05)$ during the chilled storage and below limit level at the end of chilled storage.

In the present study, the untreated and PPE \& GTE treated fish samples exhibited increase in $\mathrm{pH}$ during the entire 1-17 days of ice storage. The initial value of $6.20 \pm 0.58$, reached a value of $7.59 \pm 0.51$ in untreated fish, whereas the values found to be $6.90 \pm 0.82,7.12 \pm 0.85,7.40 \pm 0.55$ and $7.30 \pm 0.59$ in $0.5 \%$ PPE, $1 \%$ PPE, $3 \%$ GTE and $5 \%$ GTE treated fish, respectively (Figure 3). The increase in the $\mathrm{pH}$ value during storage may be attributed to the raising levels of TMA and other volatile bases in fish muscle as a result of spoilage.

Bennopur et al. (1991) reported that the $\mathrm{pH}$ of fresh mackerel (Scomber scombrus) was 5.69. It varied from 5.95 to 6.02 at different rejection times. At the end of the storage, the $\mathrm{pH}$ values were $6.24,6.29$, and 6.52, for ice: fish ratios of 1:2, $1: 3$, and 1:4, respectively. This slow rise in $\mathrm{pH}$ was observed by all of three different ice: fish ratios $(1: 2,1: 3$, and 1:4) if compared to ice: fish ratio of 1:1. Lokuruka et al. (2009) reported that the $\mathrm{pH}$ of the Nile perch (Lates niloticus) stored in ice increased 
with storage time. On day 3 , the $\mathrm{pH}$ was 6.85 . However, there was no significant increase in the $\mathrm{pH}$ until the $10^{\text {th }}$ day when it increased to 6.94 . On day 22 , when the fish was considered unacceptable for human consumption, the $\mathrm{pH}$ was 7.18.

The amount of FFA formed was more than double during the entire storage period. However significant difference was found between PPE \& GTE treated and untreated samples stored in ice. The $0.5 \%$ PPE \& $3 \%$ GTE showed a lower FFA content as compared to higher concentrations of PPE \& GTE. The PPE showed better inhibition of lipid degradation than GTE in mackerel as assayed by increased FFA content in GTE treated samples. Quitral et al. (2009) reported that the higher hydrolytic activity could be explained on the basis of the marked $\mathrm{pH}$ increase observed for untreated fish.

Comparison between individuals corresponding to Origanum vulgare (OI) and Rosmarinus officinalis (RI) conditions led to a lower $(p<0.05)$ lipid hydrolysis development at days 2 and 23 in Chilean jack mackerel (Trachurus murphyi) treated under the RI icing system. During chilled storage, FFA formation has been reported during a first stage as a result of endogenous enzyme activity (Quitral, 2009). Later on, microbial activity should be important, so that FFA formation should mostly be produced as a result of bacterial enzyme activity. A partial inhibitory effect of the plant extract on the endogenous enzyme activity occurred in the first stage (days 26 ); meanwhile, the antimicrobial effect of the plant extracts was strong lead in the second stage (days 10-23) to a lower FFA formation in the fish muscle.

\section{Microbiological analysis}

TPC of PPE \& GTE treated samples stored in ice were comparatively lower than that of untreated samples. This may be due to action of antimicrobial treatment given to the fishes. These findings are in agreement with Ibrahium; (2010), who reported that pomegranate peel extract was effective against the growth of Staphylococcus aureus, Escherichia coli, Aspergillus niger and Saccharomyces cerevisiae. The inhibitory effect of PPE increased by increasing concentrations of PPE and inhibition zones ranged from 9.6 to $25.7 \mathrm{~mm}$. The highest inhibition was obtained for E. coli while the lowest was for $S$. cerevisiae. These results provide evidence for the presence of antimicrobial phenolic compounds in PPE. These compounds degrade the cell wall, disrupt the cytoplasmic membrane, damage membrane proteins and interfere with membrane-integrated enzymes, which may eventually lead to cell death. Also, Nurmahani et al. (2012) reported that the antibacterial activity of PP \& GT plant extracts may be due to the capability of bioactive compounds to form a complex with extracellular and soluble proteins, inhibit enzyme activity and also affect bacterial cell walls.

\section{Sensory analysis}

In the present study, organoleptic score for fresh fish was taken as the main criteria for judging the quality of ice stored fish. The sensory value, on 6th day for 
control was $1.76 \pm 0.97$ which was below the level of acceptability limit. Mackerel treated with $0.5 \%$ \& $1 \%$ PPE was acceptable up to 17 days, where as those with $3 \%$ $\& 5 \%$ GTE was acceptable up to 16 days of ice storage. It indicated that both PPE \& GTE had tangible effects on increasing the shelf life of mackerel in ice storage. An extension of 8 days of shelf life was noticed due to PPE \& GTE treatment of mackerel. Physical and chemical changes in proteins of fish during ice storage caused texture deterioration. This problem also affected sensory aspects.

Mackerel treated with green tea extract was the most preferred samples in terms of sensory scores. Ababouch et al. (1996) reported that the keeping time of sardines (Sardina pilchardus) varied between 21 and $27 \mathrm{~h}$ (average $23 \mathrm{~h}$ ) for fish stored at ambient and from 8-11 days (average 9.5 days) in ice. Surendran and Iyer (1980) reported that the shelf life of pearl spot (Etroplus suratensis) in ice was 8-10 days.

\section{CONCLUSION}

Lipid oxidation and protein degradation cause unpleasant physical and sensory alterations even during ice storage. In this study, it was found that use of plant extracts as natural antioxidants have positive effects on quality parameters during ice storage. Green tea extract treatment was more preferred in terms of brightness, odor and texture aspects. The present findings will be useful in leading to further experiments on the identification and characterization of natural sources that are responsible for preservation of eating quality and extended shelf life of food products.

\section{ACKNOWLEDGEMENTS}

The authors wish to express their thanks to Dr. Balasaheb Sawant Konkan Krishi Vidyapeeth, Dapoli for funding this work and Associate Dean, Fisheries College, Shirgaon for cooperation in carrying out this study.

\section{REFERENCES}

Ababouch, L.H., Souibri, L., Rhaliby, K., Ouahdi, O., Battal, M. and Busta, F.F. 1996. Quality changes in sardines (Sardina pilchardus) stored in ice and at ambient temperature. Food Microbiology, 13: 123-131

Balachandran, K.K. 2001. Post Harvest Technology of Fish and Fish products. Daya Publishing House, Delhi, India

Bennopur, M., Marrakchi, A., Bouchriti, N., Hamama, A. and Ouadaa, M. 1991. Chemical and microbiological assessments of mackerel (Scomber scombrus) stored in ice. Journal of Food Processing and Preservation, 54 (10): 784-792

Ibrahium, M. 2010. Efficiency of pomegranate peel extract as antimicrobial, antioxidant and protective agents. World Journal of Agricultural Sciences, 6 (4): 338-344 
Khammuang, S. and Sarnthima, R.2011. Antioxidant and antibacterial activities of selectedvarieties of Thai mango seed extract. Pakistan Journal of Pharmaceutical Sciences, 24 (1): 37-42

Lokuruka, G.M. and Matofari, J. 2009. Nutritional composition and shelf life of the lakeVictoria Nile perch (Lates niloticus) stored in ice. African Journal of Food Agriculture and Nutritional Development, 9 (3): 901-919

Nurmahani, M., Osman, A., Abdul, A., Ghazali, F. and Dek, P. 2012. Short communication antibacterial property of Hylocereus polyrhizus and Hylocereus undatus peel extracts. International Food Research Journal, 19 (1): 77-84

Quitral, V., Donoso, M., Ortiz, J., Herrera, M., Araya, H. and Aubourg, S. 2009. Chemical changes during the chilled storage of Chilean jack mackerel (Trachurus murphyi) effect of a plant-extract icing system. Food Science and Technology, 42: 1450-1454

Sarah, H., Hadiseh, K., Gholamhossein, A. and Bahareh, S. 2010. Effect of green tea (Camellia sinenses) extract and onion (Allium cepa) juice on lipid degradation and sensory acceptance of Persian sturgeon (Acipenser persicus) fillets. International Food Research Journal, 17: 751-761

Simeonidou, S., Govaris, A. and Vareltzis, K. 1997. Effect of frozen storage on the quality of whole fish and fillets of horse mackerel (Trachurus trachurus) and Mediterranean hake (Merluccius mediterranean). Zeitschrift für Lebensmittel-Untersuchung und Forschung, 204: 405-410

Snedecor, G.W. and Cochran, W.G. 1967. Statistical Methods. Oxford and IBM Publishing Co., New Delhi

Spanos, G.A. and Wrolstad, R.E. 1990. Influence of processing and storage on the phenolic composition of Thompson seedless grape juice. Journal of Agriculture and Food Chemistry, 38 (7): 1565-1571

Surendran, P. and Iyer, K. 1980. Iced storage characteristics of pearl spot (Etroplus suratensis) caught from Cochin backwaters. Paper presented at Symposium on Coastal Aquaculture, Central Institute of Fisheries Technology, Cochin

Yerlikaya, P. and Gokoglu, N. 2010. Effect of previous plant extract treatment on sensory and physical properties of frozen bonito (Sarda sarda) filllets. Turkish Journal of Fisheries and Aquatic Sciences, 10: 341-349 
Table 1. Sensory evaluation scale for ice stored fish

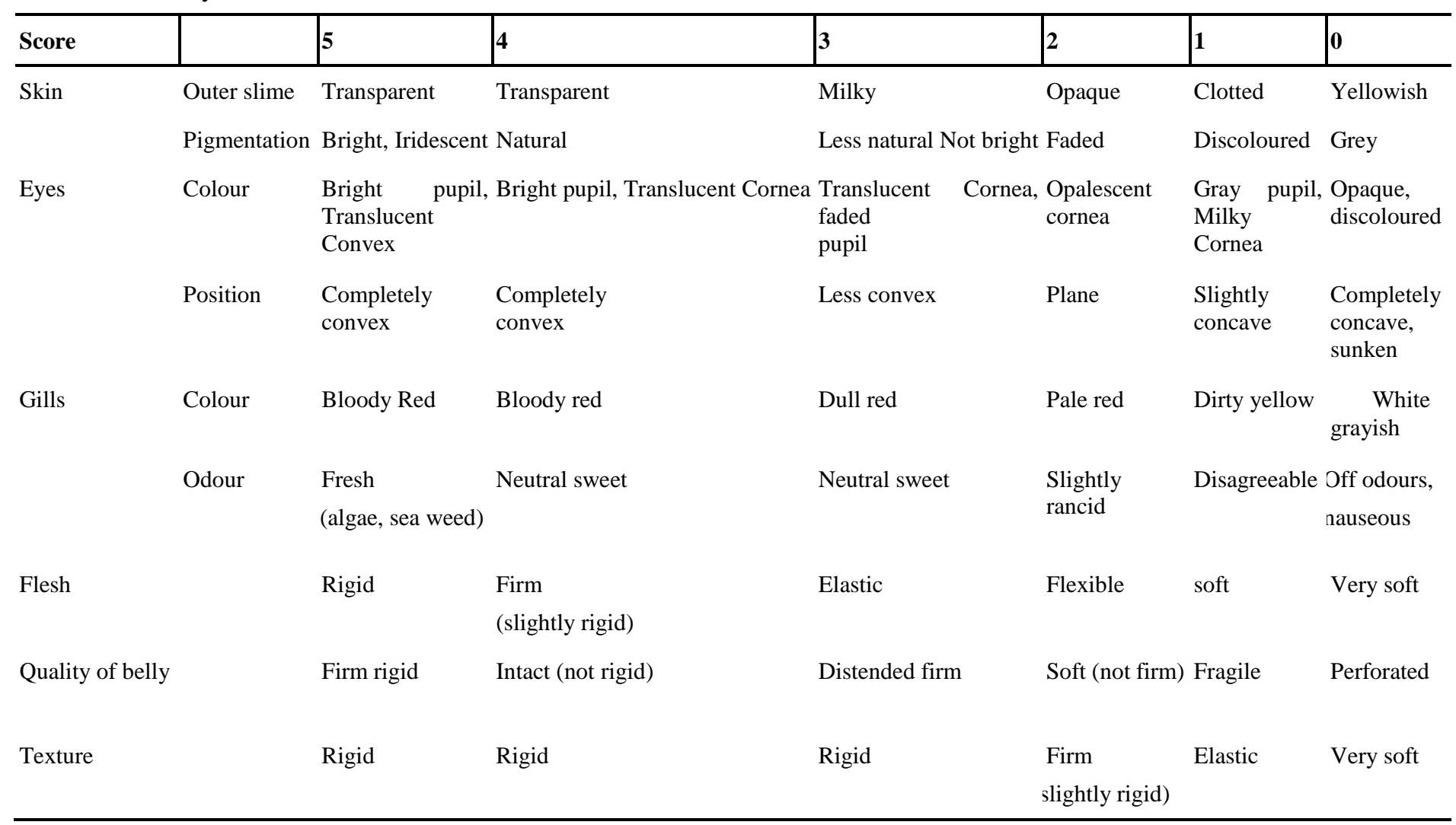

5-4 “excellent", 4-3 "good", 3-2.5 "fair", 2.5-2 "poor, 2-1 "very poor" Scores $<2.5$ is rejected 

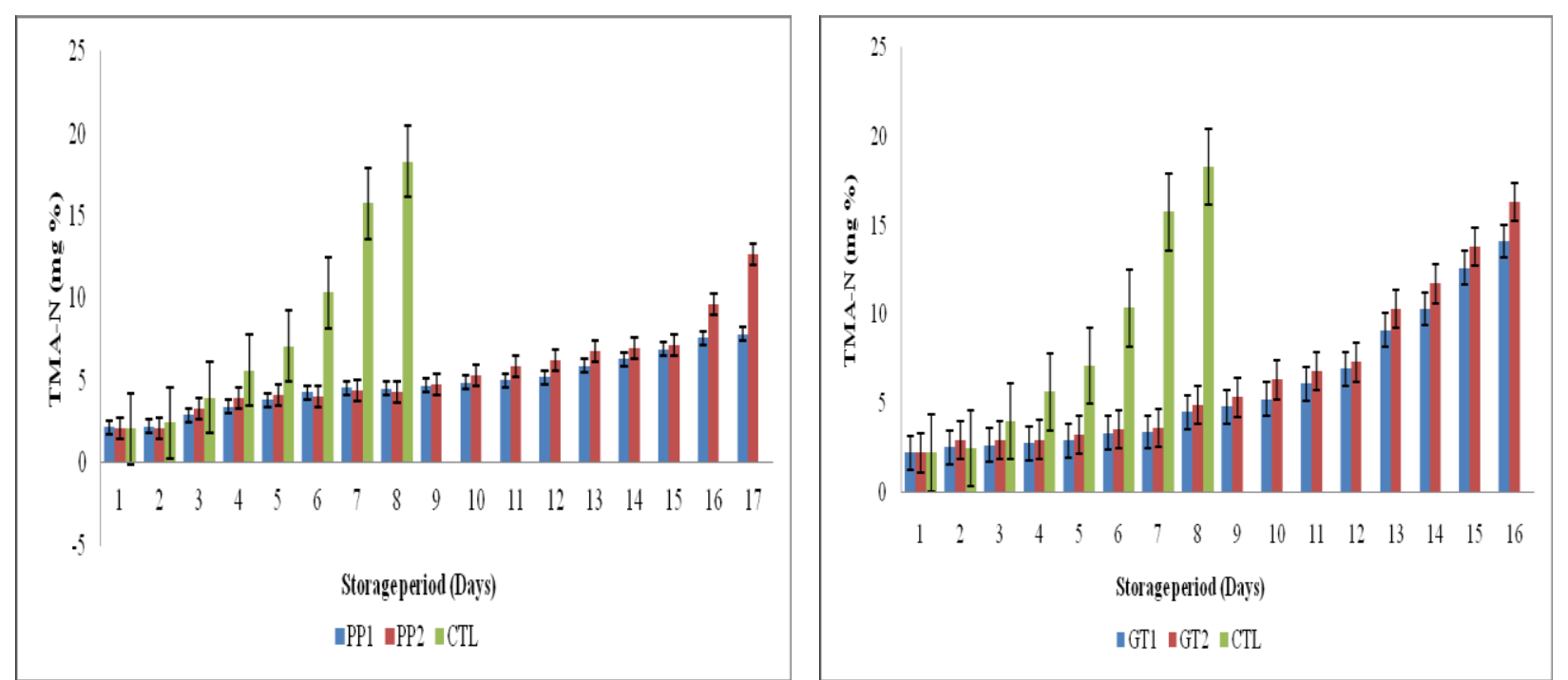

Note: PP1- 0.5\% Pomegranate peel extract, PP2- 1\% Pomegranate peel extract, GT1- 3\% Green tea extract, GT2- 5\% Green tea extract and CTLControl (untreated).

Figure 1. Changes in TMA-N (mg \%) content in pomegranate peel and green tea extract treated mackerel during ice storage 

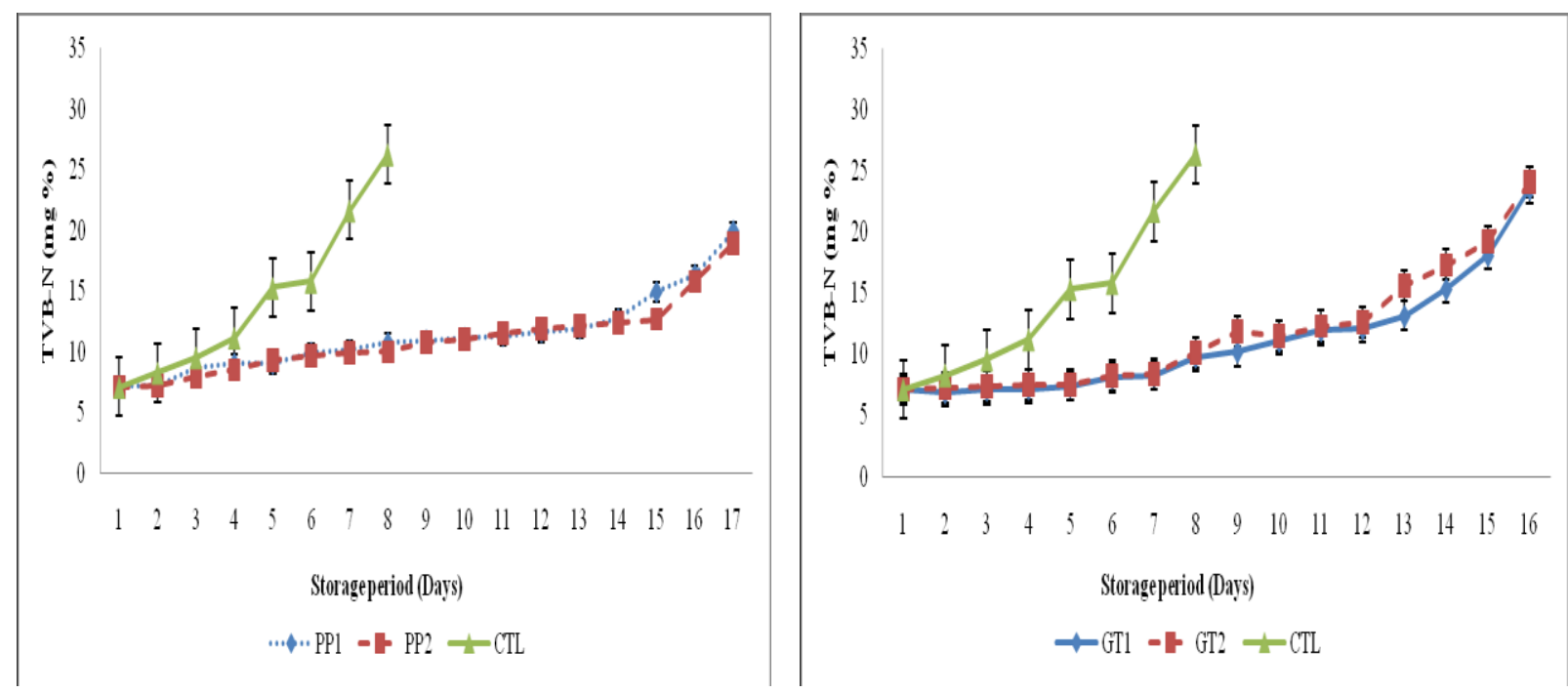

Note: PP1- 0.5\% Pomegranate peel extract, PP2- 1\% Pomegranate peel extract, GT1- 3\% Green tea extract, GT2- 5\% Green tea extract and CTL- Control (untreated). Figure 2. Changes in TVB-N (mg \%) content in pomegranate peel and green tea extract treated mackerel during ice storage 

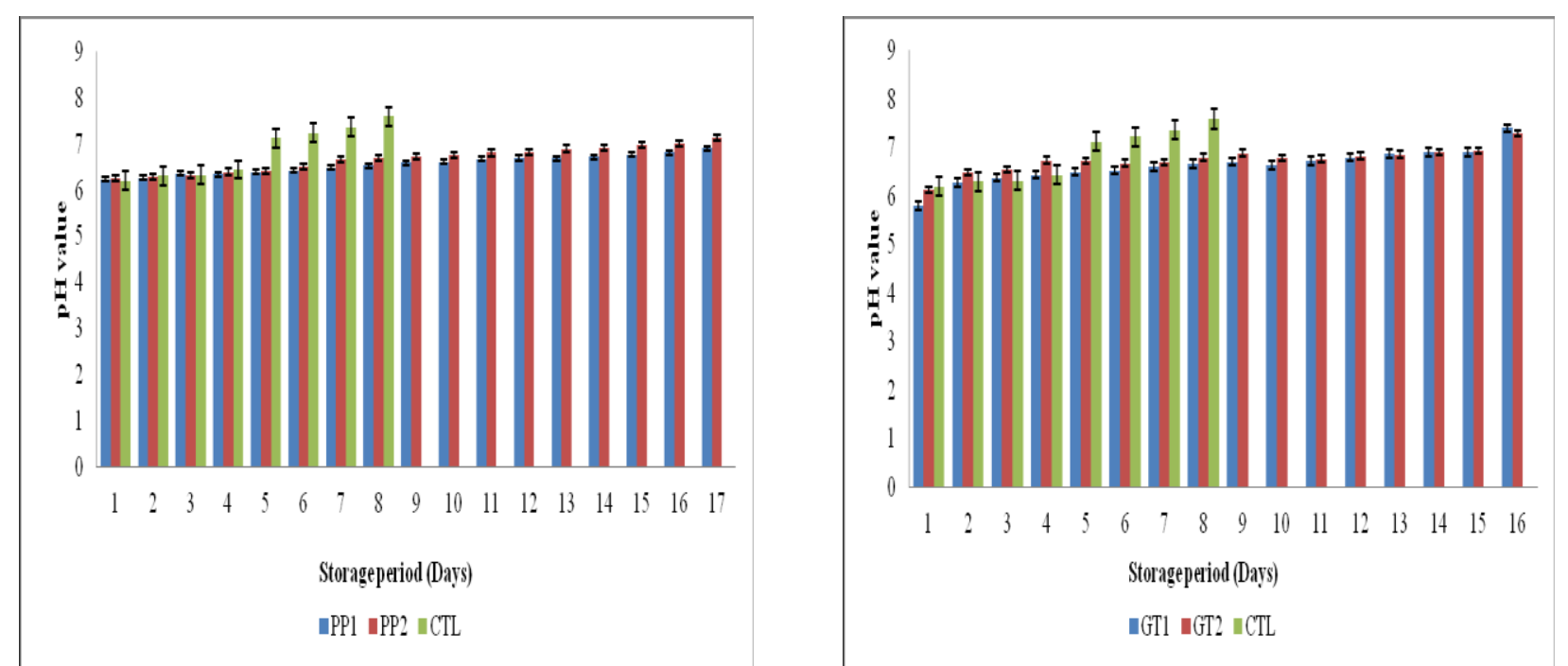

Note: PP1- 0.5\% Pomegranate peel extract, PP2- 1\% Pomegranate peel extract, GT1- 3\% Green tea extract, GT2- 5\% Green tea extract and CTLControl (untreated).

Figure 3. Changes in $\mathrm{pH}$ value in pomegranate peel and green tea extract treated mackerel during ice storage 


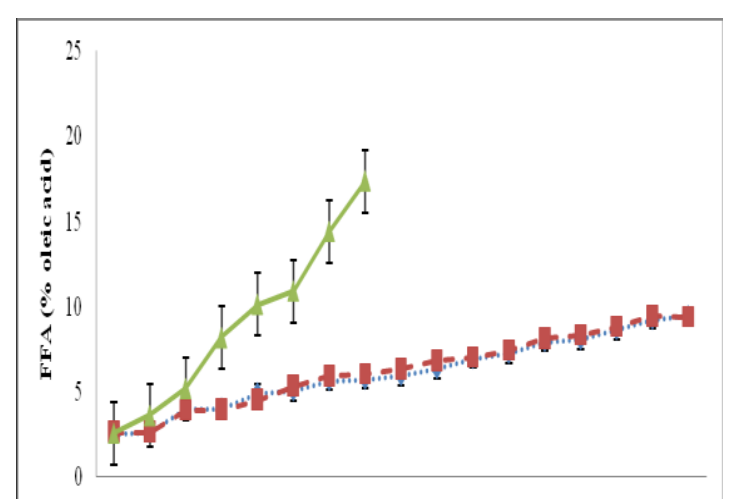

$\begin{array}{lllllllllllllllll}1 & 2 & 3 & 4 & 5 & 6 & 7 & 8 & 9 & 10 & 11 & 12 & 13 & 14 & 15 & 16 & 17\end{array}$ Storageperiod (Dayss)

… $\cdots P 1-F P P 2 \div C T L$
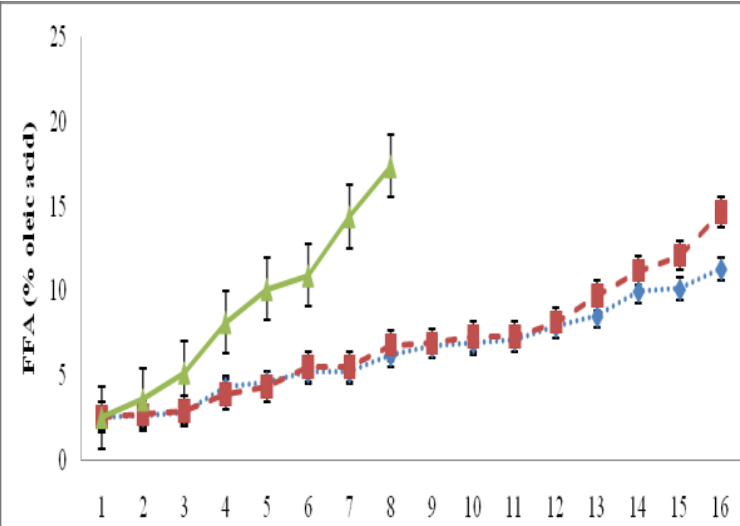
Storagẹperiod(Days)

$\cdots \leftrightarrow$ GTl - F GT2 $\leftarrow$ CTL

Note: PP1- 0.5\% Pomegranate peel extract, PP2- 1\% Pomegranate peel extract, GT1- 3\% Green tea extract, GT2- 5\% Green tea extract and CTLControl (untreated).

Figure 4. Changes in FFA (\% oleic acid) content in pomegranate peel and green tea extract treated mackerel during ice storage 

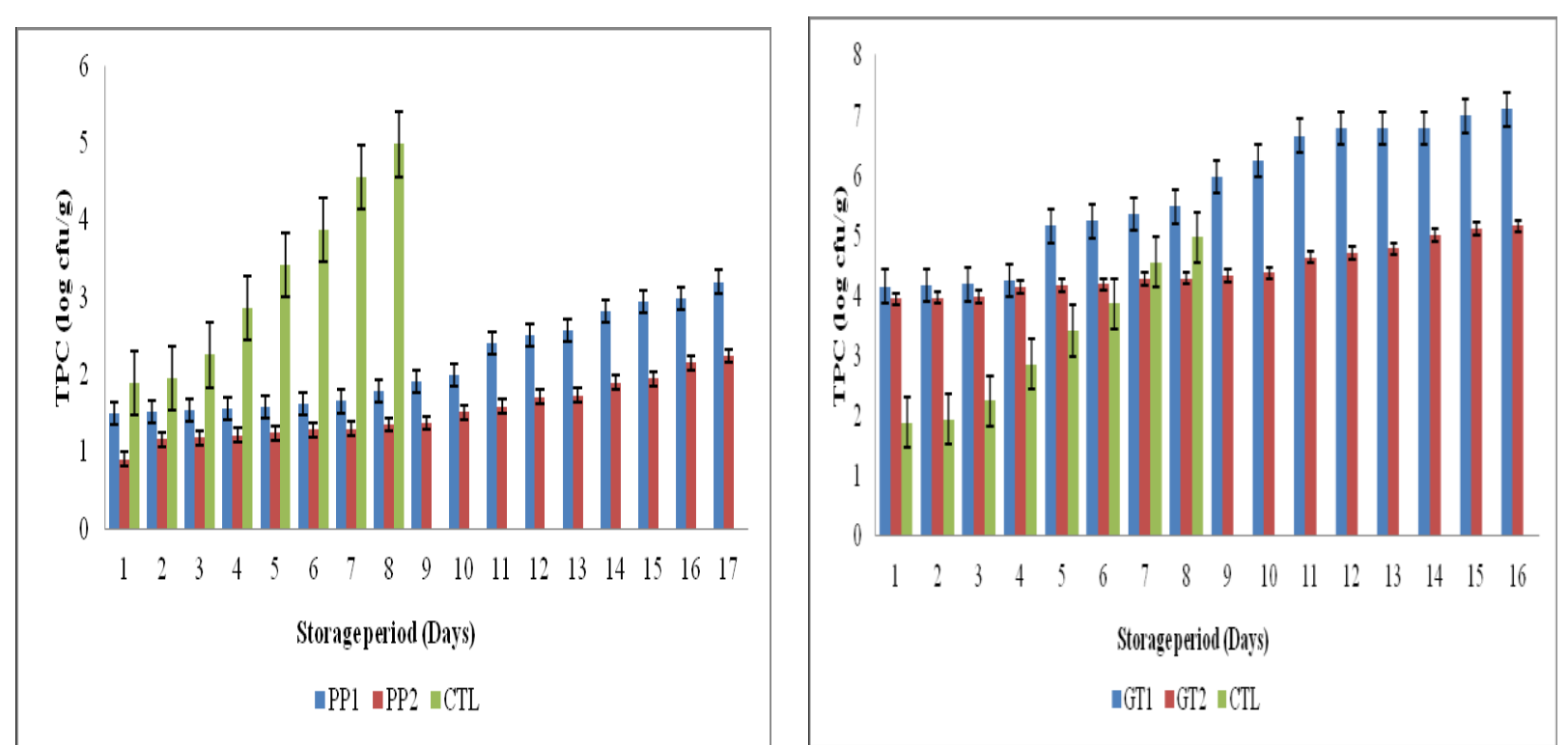

Note: PP1- 0.5\% Pomegranate peel extract concentration, PP2- 1\% Pomegranate peel extract concentration, GT1- 3\% Green tea extract, GT2- 5\% Green tea extract concentration and CTL- Control (untreated).

Figure 5. Changes in TPC (Log cfu/g) of pomegranate peel and green tea extract treated mackerel during ice storage 

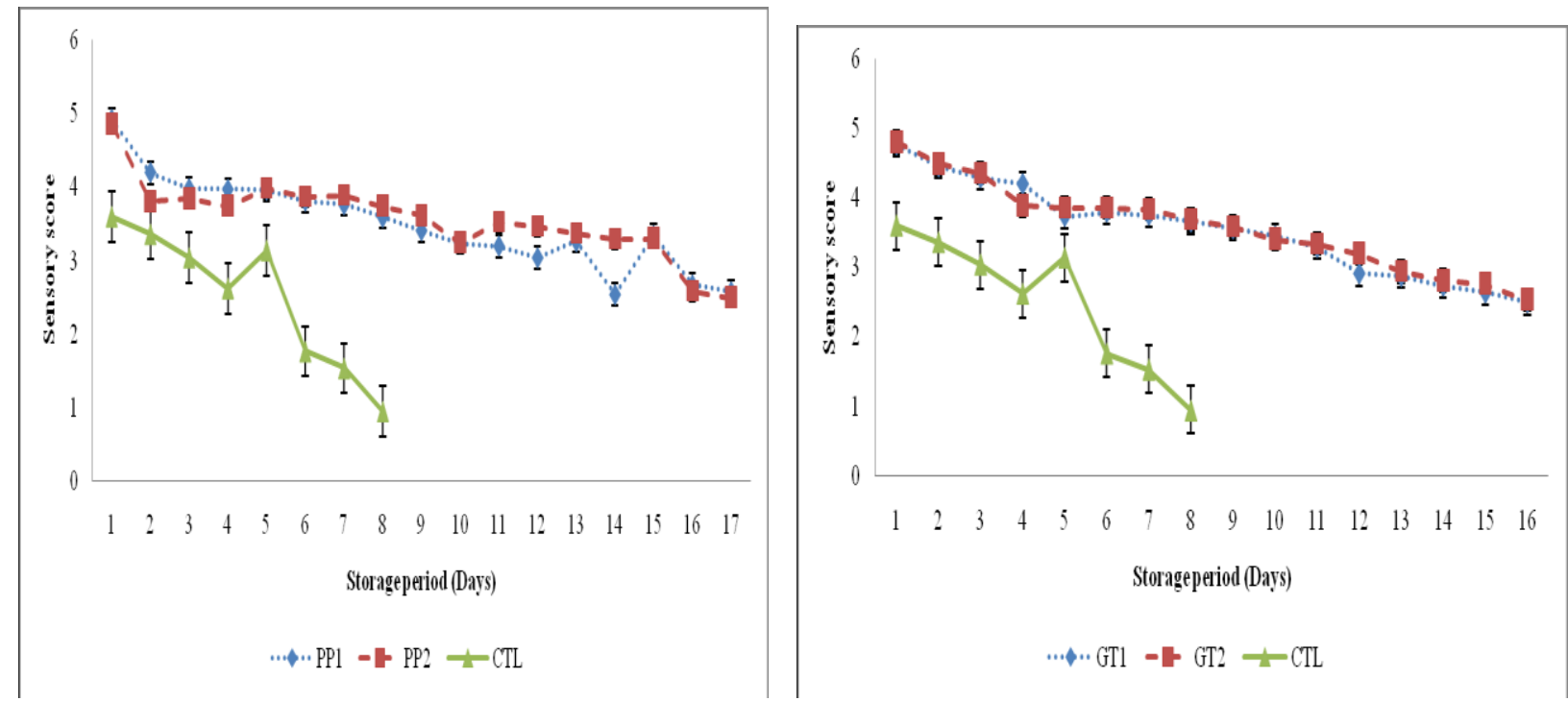

Note: PP1- 0.5\% Pomegranate peel extract concentration, PP2- 1\% Pomegranate peel extract, GT1- 3\% Green tea extract, GT2- 5\% Green tea extract and CTL- Control (untreated).

Figure 6. Sensory scores of pomegranate peel and green tea extract treated mackerel during ice storage 